\title{
Purification, partial characterization, and development of a specific radioimmunoassay for goat placental lactogen
}

\author{
W. B. Currie, C. E. Card, F. J. Michel and G. Ignotz \\ Department of Animal Science, Cornell University, Ithaca, NY 14853-4801, USA
}

\begin{abstract}
Summary. Placental lactogen (PL) was isolated from goat cotyledonary tissue by a combination of mild alkaline extraction, anion and cation exchange chromatography, chromatofocussing and molecular filtration. The product, enriched 15000 -fold from the initial extract, was homogeneous when examined by SDS-gel electrophoresis $\left(M_{\mathrm{r}} 22500\right)$ and isoelectricfocussing indicated a pI of 8.35 with a trace contaminant of pI 8.0 . When assessed by relative binding activity in radioreceptor assays (RRA), goat PL exhibited somatotropic activity equivalent to $2 \cdot 2$ units $/ \mathrm{mg}$ dry weight and lactogenic activity equivalent to 28.5 units/mg. A radioimmunoassay (RIA) for goat PL is described that is highly sensitive ( $190 \mathrm{pg} /$ tube) and has acceptable repeatability within and between assays ( 6 and $13 \%$, respectively). The assay is not affected by goat pituitary extracts or partly purified goat growth hormone and prolactin. Despite the marked increase in sensitivity of the RIA over that previously available when goat PL was measured by RRA, the hormone was not detected in jugular plasma of goats before Day 44 of pregnancy; concentrations increased thereafter and highest levels were measured during the last third of pregnancy in animals bearing triplets. Measurements by RIA are in general agreement with those obtained earlier in several studies in which RRAs were used. The hormone was detected in amniotic fluid. Maternal concentrations of goat PL declined before parturition and were undetectable by $18 \mathrm{~h}$ post partum.
\end{abstract}

Keywords: goat; placental lactogen; purification; pregnancy; radioimmunoassay

\section{Introduction}

Placental lactogens (PLs) are polypeptide hormones produced by chorionic tissue in primates, rodents and ruminants (Talamantes, 1975; Talamantes \& Ogren, 1988). Their occurrence in ruminants was established using in-vitro bioassays for lactogenic activity (Buttle et al., 1972; Forsyth, 1974) then confirmed with the introduction of radioreceptor assays (RRA) for lactogenic, or prolactin-like activity (prolactin-LA, Shiu et al., 1973; Kelly et al., 1974) and then somatotropic, or GH-like, activity (GH-LA, Kelly et al., 1976). The PL of goats, first detected by Buttle et al. (1972), has been studied extensively with RRAs (Currie \& Thorburn, 1977; Currie et al., 1977; Hayden et al., 1979, 1980, 1983). Antisera prepared against purified PLs from other species have not exhibited sufficient cross-reactivity with goat PL to permit measurement of the latter by radioimmunoassay (RIA). While Becka et al. (1977) and Chan et al. (1986) described some properties of partly purified goat PL, hormone of sufficient purity has not previously been available for development of an homologous RIA.

The present report describes the isolation of goat $\mathrm{PL}$, provides some fundamental characteristics of the molecule and then describes the development of a sensitive, specific radioimmunoassay. 


\section{Materials and Methods}

Purchased supplies. Materials used in this work and their suppliers included: Sephadex G-100, G-75 Superfine, Polybuffer Exchanger 94, Polybuffers 96 and 74, Pharmacia (Piscataway, NJ, USA); ampholines for isoelectricfocussing, LKB-Instruments (Paramus, NJ, USA); diethylaminoethyl (DEAE) cellulose and other reagents for electrophoresis, Bio-Rad Laboratories (Richmond, CA, USA); carboxymethyl (CM) cellulose, Whatman, Inc. (Clifton, NJ, USA); protein standards used as markers for molecular weights (MW-SDS-70L) and isoelectric points (IEF-M1), all tissue culture media, fetal bovine serum and adjuvants, Sigma Chemical Co. (St Louis, MO, USA); Iodo-Gen, Pierce Chemical Co. (Rockford, IL, USA); T-6l euthanasia solution, Hoechst Rousell Pharmaceuticals (Somerville, NJ, USA); Surital, Parke-Davis (Morris Plains, NJ, USA) and routine laboratory supplies, Fisher Scientific Co. (Pittsburgh, PA, USA).

Tissue sources. Placentomes were collected immediately post mortem from goats of mixed breeding at known stages of pregnancy (110-125 days after mating). The fetal cotyledons were squeezed off the caruncles, trimmed from intercotyledonary membranes, rinsed in saline and then stored at $-20^{\circ} \mathrm{C}$ for up to 9 months before extraction.

Intact pituitary glands were removed promptly after chemical euthanasia of goats without regard to physiological state. Tissues were collected and heid in sealed vials at $-20^{\circ} \mathrm{C}$ for up to 5 years before use.

Livers and mammary glands were collected from parturient rabbits and kept at $-20^{\circ} \mathrm{C}$ for up to 3 months before preparation of microsomes for radioreceptor assays (RRAs).

Jugular blood was collected from grade dairy goats at known times after mating. Animals were housed in a freestall barn during the winter and fed average quality hay and concentrates to meet requirements. Three does were moved to individual box stalls and were observed continuously until parturition. Blood was collected into heparinized glass tubes and placed on ice, centrifuged at $1000 \mathrm{~g}$ for $20 \mathrm{~min}$, and then plasma was stored at $-20^{\circ} \mathrm{C}$ until analysis. Amniotic fluid was obtained from a doe carrying a chronically catheterized fetus in late gestation.

Purification of PL. Batches of tissue ( $500 \mathrm{~g}$ wet weight) were processed as follows: frozen cotyledons were chopped coarsely, suspended in $2.5125 \mathrm{~mm}$-ammonium bicarbonate containing $100 \mu \mathrm{M}$-PMSF, adjusted to $\mathrm{pH} 9.0$ with ammonium hydroxide, then homogenized for $60 \mathrm{sec}$ at full speed in a Waring blender. The homogenate was further processed for $30 \mathrm{sec}$ at full speed using a Polytron (Brinkman Instrument Co., Westbury, NY, USA) fitted with a PT-25 generator.

After mixing for $3 \mathrm{~h}$ at $4^{\circ} \mathrm{C}$, the homogenate was adjusted to $\mathrm{pH} 8.0$ with glacial acetic acid then centrifuged for $20 \mathrm{~min}$ at $12000 \mathrm{~g}$. The supernatant was diluted with an equal volume of distilled water, adjusted to pH 7.8 with acetic acid, and batch-mixed for $1 \mathrm{~h}$ with $1250 \mathrm{~g}$ swollen wet DEAE-cellulose, equilibrated with 25 mm-ammonium borate ( $\mathrm{pH} 7.8$ ) and the mixture was maintained at $\mathrm{pH} 7.8$ during a 1-h period by addition of acetic acid. The filtrate was collected and the DEAE cellulose was washed in situ with $1125 \mathrm{mm-ammonium} \mathrm{bicarbonate,} \mathrm{pH} 7 \cdot 8$.

The filtrate and wash were pooled, adjusted to $\mathrm{pH} 6.0$ with glacial acetic acid, then batch-mixed for $1 \mathrm{~h}$ with $100 \mathrm{~g}$ (wet weight) $\mathrm{CM}$-cellulose, previously equilibrated with $50 \mathrm{~mm}$-ammonium acetate, adjusted to $\mathrm{pH} 6.0$ with acetic acid. The exchanger was collected by filtration, washed with equilibration buffer to remove coloured solute, and then with several litres of $10 \mathrm{~mm}$-ammonium bicarbonate (pH 7.8). Final washing at $\mathrm{pH} 7.8$ was performed on a bed support of polyester fibre in a separatory funnel and continued until absorbance at $280 \mathrm{~nm}$ of the filtrate was $<0 \cdot 1$.

Step-elution of $\mathrm{PL}$ was achieved with $25 \mathrm{~mm}$-ethanolamine- $\mathrm{HCl}(\mathrm{pH} 9.0)$ and the $\mathrm{pH}$ and absorbance of the eluate were used to construct a pool of minimal volume. This pool was adjusted to $\mathrm{pH} 9.4$ with ethanolamine then applied to a column packed with $10 \mathrm{ml}$ PBE 94 Polybuffer Exchanger, equilibrated with $25 \mathrm{~mm}$-ethanolamine- $\mathrm{HCl}(\mathrm{pH} 9 \cdot 4)$. The loaded column was washed with $20 \mathrm{ml}$ equilibration buffer then developed with $100 \mathrm{ml}$ Polybuffer 96 , diluted 1:15 and adjusted to $\mathrm{pH} 7.4$ with $\mathrm{HCl}$. Fractions $(2 \mathrm{ml})$ were collected and monitored for $\mathrm{pH}$, protein (by absorbance at $280 \mathrm{~nm}$ ), GH-LA and/or prolactin-LA (by RRAs, see below).

Fractions containing PL were pooled, concentrated by precipitation and washing with ammonium sulphate ( $80 \%$ saturation) to remove Polybuffer components, then dissolved in about $1-1.5 \mathrm{ml}$ distilled water. Final purification was achieved by chromatograhy on a column of analytical dimensions $(12 \mathrm{~mm}$ i.d. $\times 120 \mathrm{~cm})$, packed with Sephadex G$75 \mathrm{SF}$, equilibrated with $10 \mathrm{~mm}$-ammonium bicarbonate $(\mathrm{pH} 8.0)$. Fractions of $2 \mathrm{ml}$ volume were collected, monitored as described above, then were pooled on the basis of specific activity and lyophilized.

Isolation of $\boldsymbol{G H}$ and prolactin. The method used was developed from that of McNeilly \& Andrews (1974) for goat prolactin and, as modified, enables simultaneous isolation of both prolactin and GH. Frozen tissue ( 5 pituitaries) was homogenized for $30 \mathrm{sec}$ in 5 volumes of the extractant used for PL, using the Polytron fitted with a PT-10 generator. The homogenate was stirred for $15 \mathrm{~min}$, rehomogenized and stirred for a further $15 \mathrm{~min}$, and then centrifuged at $48000 \mathrm{~g}$ for $30 \mathrm{~min}$ at $4^{\circ} \mathrm{C}$. The supernatant was fractionated on a column $(16 \mathrm{~mm}$ i.d. $\times 95 \mathrm{~cm}, 190 \mathrm{ml}$ bed volume $)$ packed with Sephadex G-100 and eluted with $10 \mathrm{~mm}$-diethanolamine- $\mathrm{HCl}(\mathrm{pH} 8 \cdot 5)$. Fractions $(2.5 \mathrm{ml})$ were monitored for protein, GH and prolactin, as described above. Fractions containing both $\mathrm{GH}$ and prolactin were pooled and chromatofocussed on $5 \mathrm{ml} \mathrm{PBE} \mathrm{94,} \mathrm{equilibrated} \mathrm{with} 10 \mathrm{~mm}$-diethanolamine- $\mathrm{HCl}(\mathrm{pH} 8.5)$. The column was eluted with a mixture of Polybuffer 96 and $74(40: 60, \mathrm{v} / \mathrm{v})$, diluted 10-fold and adjusted to pH 5 with $\mathrm{HCl}$. Fractions $(0.7 \mathrm{ml})$ were monitored for $\mathrm{pH}$ and protein (absorbance at $280 \mathrm{~nm}$ ). Fractions of $\mathrm{pH} 8 \cdot 2-7.0$ were assayed for GH and those of $\mathrm{pH} 6.5-5.6$ were assayed for prolactin, each by the respective RRAs. Appropriate fractions were pooled, brought to $80 \%$ saturation with ammonium sulphate, precipitates were collected at $48000 \mathrm{~g}$ for $15 \mathrm{~min}$, washed with $80 \%$ saturated ammonium sulphate and then recentrifuged to remove Polybuffer components. Each precipitate was 
dissolved in $1-1.5 \mathrm{ml}$ distilled water and fractionated on Sephadex G-75 SF, as described for PL. Fractions ( $2 \mathrm{ml})$ were monitored for protein (absorbance at $280 \mathrm{~nm}$ ) and either $\mathrm{GH}$ or prolactin by RRA, aliquants were saved for electrophoresis, and then the remainder was lyophilized.

Radioreceptor assays. The radioreceptor assay (RRA) for GH-LA was essentially as described by Tsushima \& Friesen (1973) except for minor procedural differences. Bovine GH (Miles Lot 13, 1.2 IU/mg) or goat GH, isolated in this work, was used to prepare ${ }^{125} \mathrm{I}$-labelled $\mathrm{GH}$ and for assay standards. Tracers were prepared by reacting $500 \mu \mathrm{Ci}$ ${ }^{125} \mathrm{INa}$ with $5 \mu \mathrm{g} \mathrm{GH}$ for $4 \mathrm{~min}$ in $50 \mu \mathrm{l}$ of $50 \mathrm{~mm}$-Tris $\mathrm{HCl}(\mathrm{pH} \mathrm{7.5)}$ in tubes that were previously coated with $5 \mu \mathrm{g}$ Iodo-Gen. All GH RRAs were performed at $37^{\circ} \mathrm{C}$ for $45 \mathrm{~min}$. The RRA for prolactin-LA (Shiu et al., 1973) was modified slightly in the use of bovine prolactin $(\mathrm{NIH}$, Lot B-18, 28 IU/mg) or goat prolactin, isolated here, for preparation of tracer and for standards. Tracer was prepared using Iodo-Gen as above except the reaction time was only $1 \mathrm{~min}$. Prolactin-LA was usually determined using overnight incubation at room temperature. Goat PL was iodinated by the same method except using an 8 min reaction time. ${ }^{125}$ I-labelled goat PL was used in both GH-LA and prolactin-LA RRAs with either goat PL or appropriate pituitary hormones as standards.

Electrophoresis. SDS-polyacrylamide electrophoresis (SDS-PAGE) was performed in 11.5\% slab gels (Laemmli, 1970). Samples ( $5 \mu \mathrm{g}$ protein) and molecular weight markers were stacked at $5 \mathrm{~mA}$ for $30 \mathrm{~min}$ then separated at $30 \mathrm{~mA}$ for $3 \mathrm{~h}$. Gels were fixed overnight in 2 changes of $30 \%$ methanol:5\% acetic acid $(\mathrm{v} / \mathrm{v})$, stained with $0 \cdot 2 \%$ Coomassie Blue R-250 in 50\% methanol, destained with 30\% methanol, dried onto cellophane and photographed.

Isoelectricfocussing was performed on a flat-bed apparatus (LKB Multiphor), using $0.5 \mathrm{~mm}$ gels of $5 \%$ acrylamide (acrylamide:bis $32: 1$, w:w) containing $2.5 \% \mathrm{pH} \mathrm{3.5-10} \mathrm{ampholines.} \mathrm{Gels} \mathrm{were} \mathrm{prefocussed} \mathrm{for} 10 \mathrm{~min}$ at $25 \mathrm{~W}$. Protein samples $(5-10 \mu \mathrm{g})$ were focussed at $10^{\circ} \mathrm{C}$ using constant power $(25 \mathrm{~W}$, until a maximum of $2000 \mathrm{~V}$ was attained), for a total of $50 \mathrm{~min}$. Gels were fixed using 4 changes $(30 \mathrm{~min}$ ) of $5 \%$ trichloroacetic acid and $10 \%$ sulphosalicylic acid, then water for $15 \mathrm{~min}$ and finally $30 \%$ methanol for $15 \mathrm{~min}$. Gels were stained with $0.2 \%$ Coomassie Blue R-250 in $30 \%$ methanol and $8 \%$ acetic acid, then destained, dried and photographed as described above.

Characteristics of rabbit anti-goat PL and a radioimmunoassay for goat PL. Antisera to goat PL were raised in rabbits using $50 \mu \mathrm{g}$ protein (in Freund's Complete Adjuvant) for primary immunization and multiple periodic boosts with $25 \mu \mathrm{g}$ goat PL (in Freund's Incomplete Adjuvant). Blood was withdrawn by cardiac puncture during brief anaesthesia with pentobarbitone sodium, and clotted overnight; serum samples were kept at $-20^{\circ} \mathrm{C}$. Test sera were diluted in phosphate buffered saline (PBS) containing $50 \mathrm{~mm}$-disodium ethylenediaminetetraacetic acid, $0.25 \mathrm{~mm}$ sodium merthiolate and 1:400 non-immunized rabbit serum. Aliquants ( $100 \mu l)$ of diluted sera with approximately 20000 c.p.m. freshly prepared ${ }^{125} \mathrm{I}$-labelled goat PL were incubated overnight at $4^{\circ} \mathrm{C}$ in a final volume of $400 \mu \mathrm{l}$ made up with PBS containing $0.25 \mathrm{~mm}$-sodium merthiolate and $0.1 \%(\mathrm{w} / \mathrm{v})$ gelatin (gel-PBS). On the second day, a $1: 25$ dilution of ovine anti-rabbit gamma globulin was added and incubation continued for a further $24 \mathrm{~h}$. Bound and unbound ${ }^{125}$ I-labelled PL were separated after diluting the contents of tubes with $3 \mathrm{ml}$ ice-cold gel-PBS and centrifuging at $1000 \mathrm{~g}$ for $20 \mathrm{~min}$.

In routine use, the RIA for PL was performed as above with standard amounts of PL in gel-PBS (100 $\mu$ l) or with unknown samples $(<200 \mu \mathrm{l})$ included within the initial $400 \mu \mathrm{l}$ incubation volume. Non-specific binding of ${ }^{125} \mathrm{I}$. labelled PL, assessed by omitting the antibody, seldom exceeded 3 times background for the gamma counter. Using a final antiserum dilution of 64000 , binding of ${ }^{125}$ I-labelled PL in the absence of added unlabelled PL $\left(B_{0}\right)$ was typically $30-35 \%$. At this antiserum dilution, logit-transformed binding was linearly related $\left(R^{2}>0.98\right)$ to the log of added PL between $190 \mathrm{pg}$ and $50 \mathrm{ng} /$ tube.

Specificity testing within the RIA has been confined to assessing cross-reactivity with the relevant pituitary hormones (goat PL and goat GH, as isolated here) and to determining possible interference in the assay from various volumes $(10-200 \mu \mathrm{l})$ of plasma and serum from goats not expected to contain PL, i.e. males and non-pregnant females. Additionally, because the assay is to be used with conditioned tissue culture media, Dulbecco's MEM, Medium 199 and Ham's F-12, all containing $10 \%$ fetal bovine serum, were also substituted (25-200 $\mu$ l) within multiple standard curve assays.

Further validation testing involved assaying goat plasmas containing moderate to high concentrations of endogenous PL at various dilutions to assess parallelism with the purified standard and an assessment of the recovery of purified PL used to enrich the endogenous content of selected serum and plasma samples. Finally, estimates of repeatability have been obtained during extensive use of the assay (in excess of 8000 samples) over a period of 12 months. Plasma pools were included at 2 dilutions in each of 60 assays; intra- and inter-assay coefficients of variation and were $6 \%$ and $13 \%$, respectively.

\section{Results}

\section{Isolation of goat PL}

The isolation protocol was optimized from several dozen pilot procedures and, as described here, requires 3 days from the start until the purified hormone is frozen for lyophilization. The content of extractable PL was highest, but still only about $10-15 \mu \mathrm{g} / \mathrm{g}$ wet weight, in fetal cotyledons collected before Day 135 of pregnancy, and lowest $(<2 \mu \mathrm{g} / \mathrm{g}$ in cotyledons from placentas 
delivered vaginally at term. Extraction efficiency was optimal under mildly alkaline conditions and the relative amount of $\mathrm{PL}$ to total protein was maximal at $\mathrm{pH} 9 \cdot 0$. Yield was slightly greater after extracting for $6 \mathrm{~h}$ rather than the $3 \mathrm{~h}$ used here.

Goat PL was slightly cationic at pH 7.8 when anion exchange (DEAE) was used to remove the most acidic components in the crude extract. The non-absorbed fraction therefore contained almost all of the immunoassayable PL and $25-30 \%$ of the total protein in the initial extract (Table 1). When RRAs were used to monitor the purification, lack of parallelism between dilutions of these crude early fractions with purified goat PL or the appropriate pituitary standards prevented accurate quantification of recoveries and yields. The filtrate that was excluded from DEAEcellulose at $\mathrm{pH} 7.8$ could be acidified to $\mathrm{pH} 6.0$ without visible precipitation, whereas when the crude extract was acidified below $\mathrm{pH} 7 \cdot 5$, substantial precipitation occurred, with concurrent loss of PL.

Table 1. Summary of purification of goat placental lactogen from a $500 \mathrm{~g}$ wet weight batch of cotyledons

\begin{tabular}{|c|c|c|c|c|c|}
\hline Fraction & $\begin{array}{l}\text { Goat placental } \\
\text { lactogen* } \\
\text { (mg) }\end{array}$ & $\begin{array}{l}\text { Proteint } \\
\text { (mg) }\end{array}$ & $\begin{array}{l}\text { Specific } \\
\text { activity } \\
(\mathrm{mg} / \mathrm{mg})\end{array}$ & \multicolumn{2}{|c|}{$\begin{array}{l}\text { Purification } \\
\text { (fold) }\end{array}$} \\
\hline Crude extract & $7 \cdot 25$ & 38000 & 0.00019 & $1 \cdot 0$ & \\
\hline After DEAE-cellulose & $6.59(91 \%) \ddagger$ & $12667(33 \%) \ddagger$ & 0.00052 & $2 \cdot 74$ & $(2 \cdot 7) \ddagger$ \\
\hline After CM-cellulose & $5.27(80 \%)$ & $56.26 \quad(0.4 \%)$ & 0.094 & $493 \quad($ & $(179.9)$ \\
\hline After chromatofocussing & $3 \cdot 27(62 \%)$ & $7 \cdot 43(13 \%)$ & 0.44 & 2317 & $(4 \cdot 7)$ \\
\hline After gel filtration & $2.71(83 \%)$ & $0.93(12.5 \%)$ & $2 \cdot 9$ & 15292 & $(6 \cdot 6)$ \\
\hline
\end{tabular}

${ }^{*}$ By radioimmunoassay, after diluting 1:10 to $1: 1000$.

†Estimated from absorbance at $280 \mathrm{~nm}$.

$\ddagger$ Values in parentheses are relative to preceding step.

Cation exchange using batch methods and $\mathrm{pH}$ adjustment to effect selective elution, was rapid (about $3 \mathrm{~h}$ overall), powerful (180-fold increase in specific activity) and efficient ( $>80 \%$ recovery, relative to the preceding step) and minimized the volume of material to be loaded onto the chromatofocussing column. The buffer used to elute the PL off the CM-cellulose caused a sharp increase in $\mathrm{pH}$ coincident with the appearance of hormone in the eluate. Elution of the PL was complete by the time that $\mathrm{pH}$ of the eluate had reached that of the eluting buffer (Fig. 1a). To illustrate the performance of the steps with greater precision, the concentrations of PL were measured using the RIA rather than the RRA for GH-LA that was routinely employed because of its rapidity.

The steps before obtaining the pool from the CM-cellulose were so highly repeatable between batches that there was no need routinely to monitor PL activity by RRA when moving from one step to the next; monitoring $\mathrm{pH}$ and absorbance at $280 \mathrm{~nm}$ sufficed. The buffer used at this stage was readily adjusted to be directly compatible with the equilibrated chromatofocussing medium. As a rule, the chromatofocussing column was loaded overnight on the first day and developed during the following morning.

Chromatofocussing resulted in a further 4.5-5-fold purification with about $60 \%$ recovery, relative to the loaded material (Fig. 1b). The Polybuffer components were efficiently removed by precipitating and washing the PL with ammonium sulphate, as evidenced by the absence of diffusely stained material in the low molecular weight region when focussed fractions were examined by SDS-PAGE.

Gel filtration of the concentrated fraction was performed using a column with analytical dimensions; the salt-precipitated PL was readily dissolved in 1-2 $\mathrm{ml}$ distilled water. The material was efficiently separated with PL being clearly resolved from a major peak of higher molecular weight material. The peak of activity, detected by RIA, eluted a little more sharply than did protein, as assessed by absorbance (Fig. 1c), but SDS-PAGE of individual fractions within the peak showed 
no significant heterogeneity. Recovery, relative to the chromatofocussed material, ranged from 75 to $85 \%$ for an additional 6-7-fold of purification. Overall purification, based on RIA measurements and absorbance, exceeded 15000 -fold.
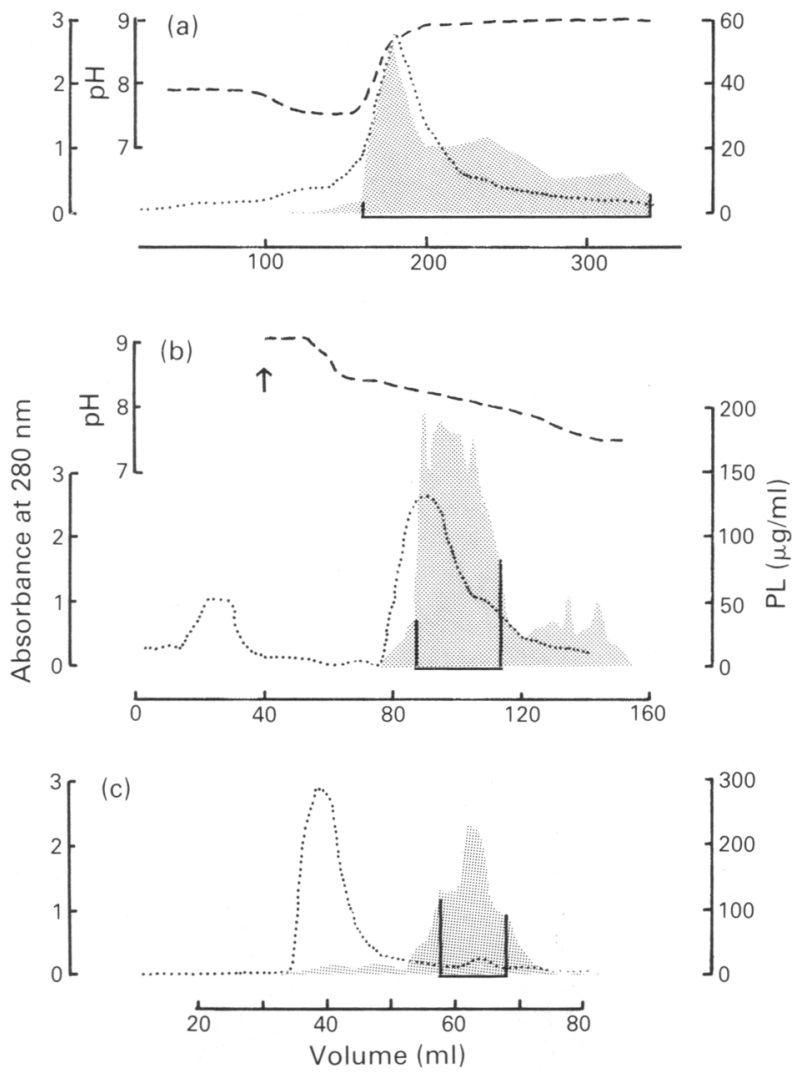

Fig. 1. Purification of goat placental lactogen (PL). (a) Elution of carboxymethyl cellulose in semi-batch mode using $25 \mathrm{~mm}$-ethanolamine- $\mathrm{HCl}$ at $\mathrm{pH} 9$, showing $\mathrm{pH}\left(--{ }_{-}\right)$, absorbance $(\cdots)$ and PL (shaded) in $20 \mathrm{ml}$ fractions. (b) Development of Polybuffer Exchanger with

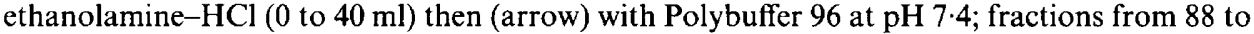
$114 \mathrm{ml}$ (vertical marks) were pooled. (c) Final gel-filtration step showing elution of PL and absorbance. Fractions eluting from 58 to $68 \mathrm{ml}$ (vertical marks) were pooled for lyophilization.

\section{Isolation of goat GH and goat prolactin}

Fractions containing GH and prolactin, which intentionally were not resolved from each other under the conditions used for gel filtration of pituitary extracts, represented about $25 \%$ of the bed volume of the column. The elution peak for GH off Sephadex G-100 consistently preceded that of prolactin (Fig. 2a). The absorbance and pH profiles of the chromatofocussing step (Fig. 2b) reliably identified the fractions containing $\mathrm{GH}$ (peak absorbance and RRA activity at $\mathrm{pH} 7.6$ ) and prolactin (peak absorbance and RRA activity at $\mathrm{pH} 5.7$ ). The absorbance profile has proved to be adequate for selecting fractions to pool for salt precipitation, thus obviating the need to delay purification while awaiting RRA data. The final gel filtration steps for each of the hormones separated the polypeptides of interest from variable amounts of high molecular weight contaminants (Fig. $2 c \&$ 
d) and some residual Polybuffer components, and served to eliminate ammonium sulphate from the preparations. Slight differences in the ratio of activity (from RRA) to absorbance at $280 \mathrm{~nm}$ within the peak reflected minor contamination of the hormone preparations with other peptides. As a routine, the final pools were constructed on the basis of specific activity, determined in this manner. Since the objective was to purify GH and prolactin for use as analytical standards, yield was compromised in favour of purity; for less demanding use, yield could be increased by being less discriminating when constructing pools for lyophilization.
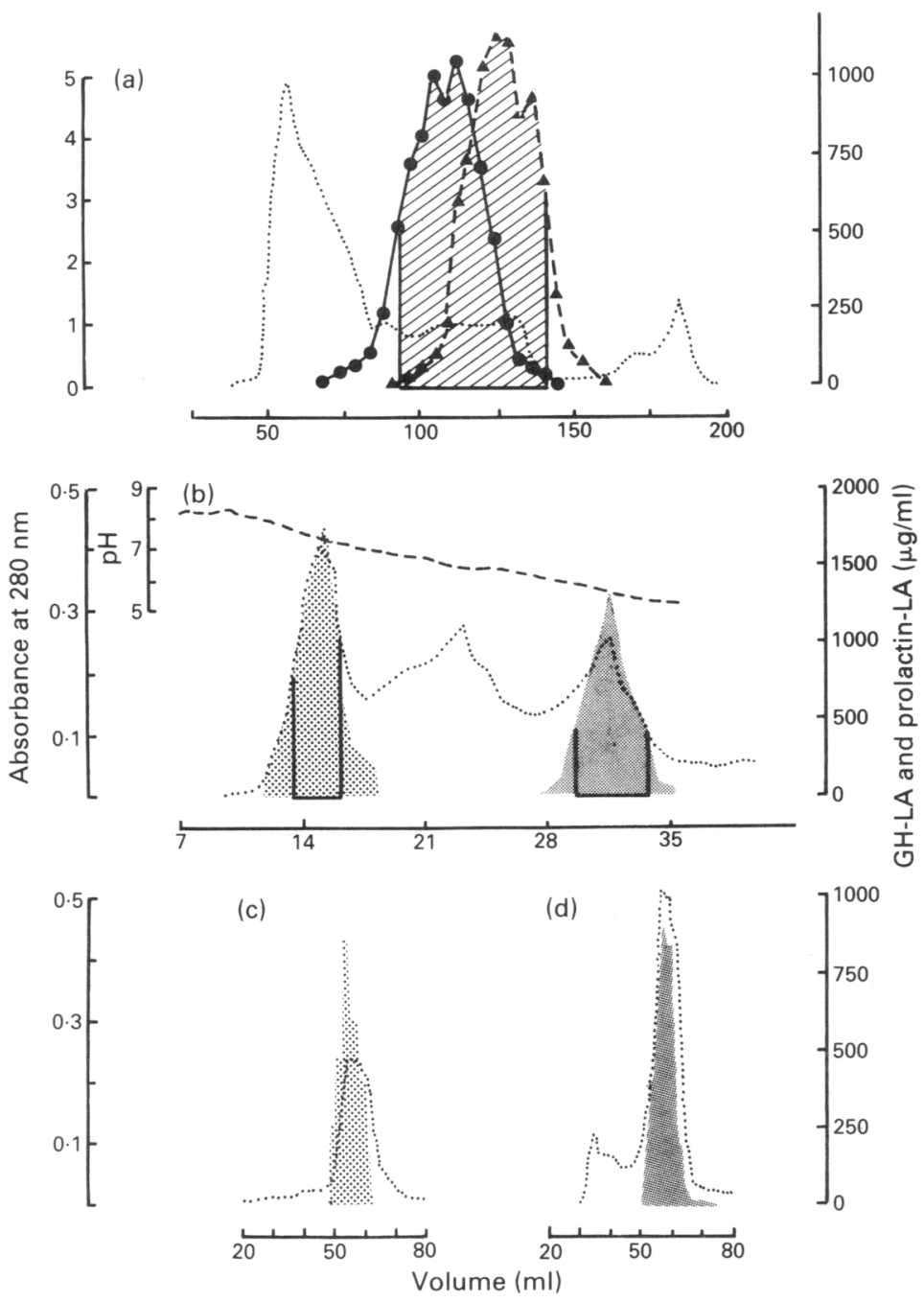

Fig. 2. Isolation of goat growth hormone (GH) and prolactin. (a) Preparative gel filtration of pituitary extract shows elution of protein (absorbance $\cdots$ ) GH ( $(\mathbf{\Delta}---\mathbf{\Delta})$. The shaded fractions were pooled for chromatofocussing. (b) Development of Polybuffer Exchanger showing typical profiles for $\mathrm{pH}$ and absorbance. The shaded areas represent GH (12-19 $\mathrm{ml})$ and prolactin $(26.6-35 \mathrm{ml})$, measured by radioreceptor assays. Vertical marks show fractions pooled for final gel-filtration of GH (c) and prolactin (d). 


\section{Electrophoretic characterization}

SDs and electrofocussing gels are shown in Fig. 3. The preparation of goat PL purified here was estimated to have a molecular weight of 22500 from SDS-PAGE. Comparable estimates for goat $\mathrm{GH}$ and prolactin were 21500 and 23500 , respectively. Using broad range isoelectricfocussing on thin gels, the pI of goat PL was estimated to be $8 \cdot 35 \pm 0 \cdot 2$ ( 3 determinations from different batches), with only one slightly more acidic contaminant. The preparation of goat prolactin (pI 5.6) showed no heterogeneity while goat $\mathrm{GH}(\mathrm{pI} 7 \cdot 3)$ did contain a slightly more basic contaminant.

\section{6}

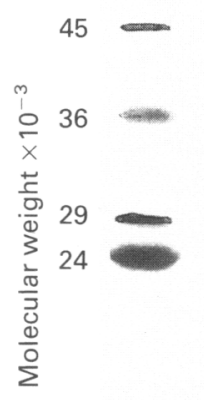

20

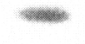

14

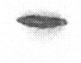

1 (a)

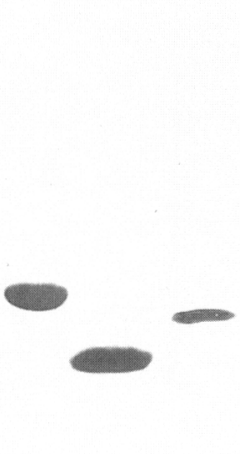

2

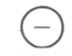

,

8

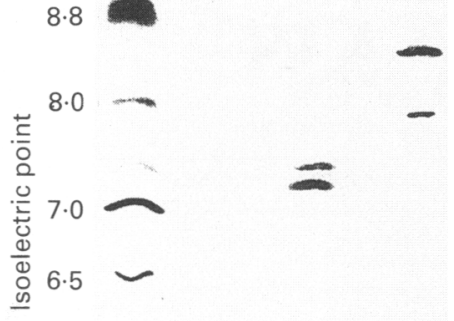

Fig. 3. Electrophoretic characterization of goat placental lactogen, growth hormone, and prolactin. SDS-gel electrophoresis (a) and analytical thin-layer isoelectricfocussing (b) of molecular weight or isoelectric point calibration standards (1), goat prolactin (2), goat GH (3) and goat PL (4).

\section{Radioreceptor assay potencies}

On the basis of dry protein weight, goat PL had a relative binding activity 1.4 times that of bovine prolactin (NIH Lot B18) in the prolactin-LA RRA (Fig. 4a), using rabbit mammary microsomes with ${ }^{125}$ I-labelled goat PL as the radiolabelled ligand. In the GH-LA RRA using rabbit hepatic microsomes and ${ }^{125}$ I-labelled goat PL as the radioligand, serial dilutions of goat PL did not parallel those of either bovine GH or our goat GH (Fig. 4b); the lack of parallelism was consistent over 4 preparations of goat PL and with microsomal preparations from 3 rabbits. It is, however, apparent that goat PL competed more effectively (approximately 3 times) than did either GH preparation for binding sites occupied by ${ }^{125}$ I-labelled goat PL. In comparable tests using ${ }^{125}$ Ilabelled goat $\mathrm{GH}$ as the radioligand, binding competition curves could not be shown to have different slopes $(P>0.05)$ and goat PL exhibited relative binding activity 1.8 times that of bovine GH (Miles Lot 13).

The preparations of goat prolactin and GH competed for binding in the respective RRAs (Figs $4 \mathrm{a} \& \mathrm{~b}$ ) with the former being about $51 \%$ as effective as bovine prolactin and goat $\mathrm{GH}$ being $93 \%$ 
as active as the bovine GH reference preparation. They showed minimal cross-reaction in heterologous assays, i.e. goat $\mathrm{GH}$ did not compete with ${ }^{125} \mathrm{I}$-labelled goat PL for binding to mammary microsomes but goat prolactin at $1 \mu \mathrm{g}$ per tube displaced ${ }^{125} \mathrm{I}$-labelled goat PL to $90 \%$ of $\mathrm{B}_{\mathrm{o}}$ values for hepatic microsomes, i.e. goat prolactin was about $0 \cdot 2 \%$ as active as goat $\mathrm{PL}$.
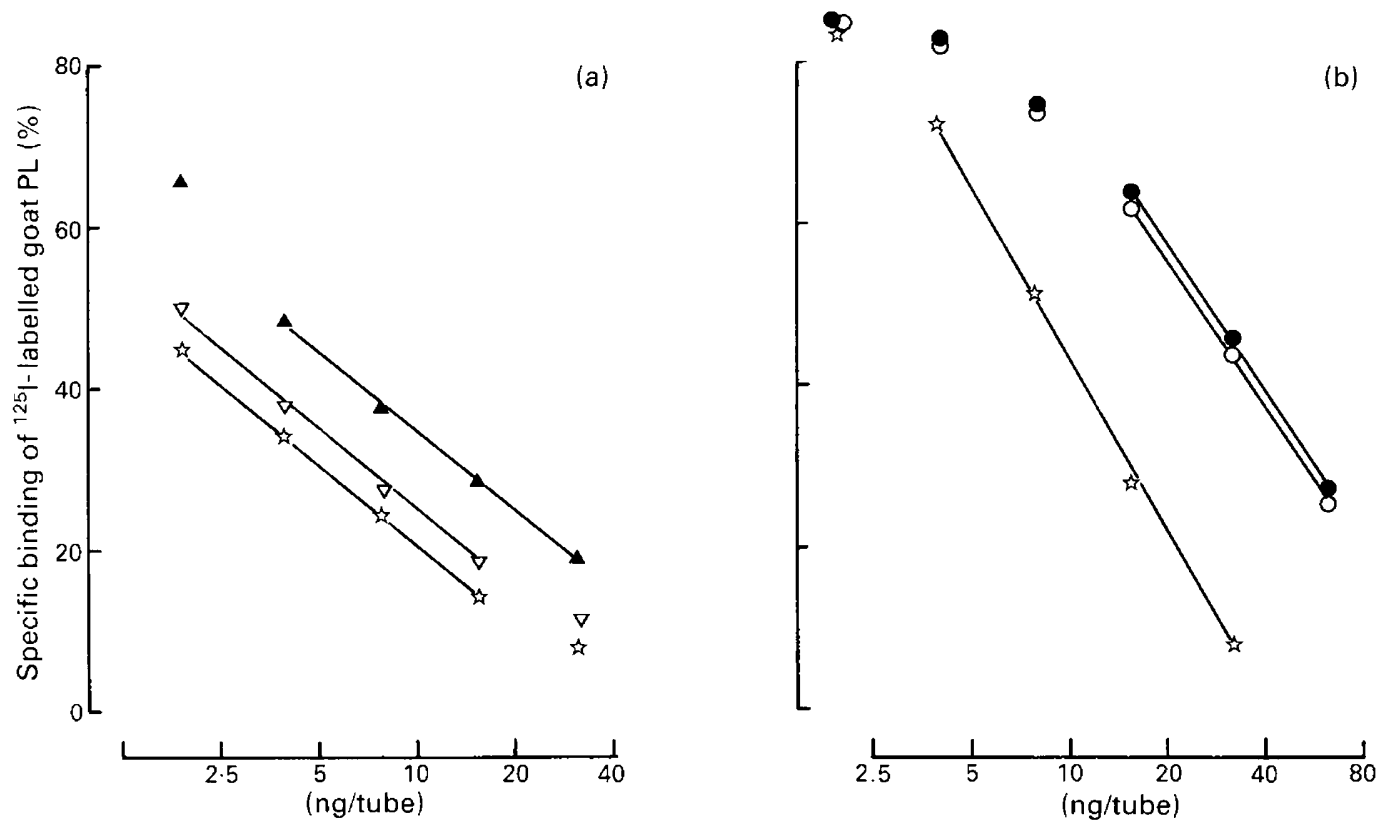

Fig. 4. Characterization of the binding of ${ }^{125}$ I-labelled goat placental lactogen (PL) to crude membranes prepared from (a) mammary and (b) hepatic tissue from rabbits. In (a), competitive binding curves for radioinert PL $(\hat{\sim})$, bovine prolactin $(\nabla)$ and goat prolactin $(\boldsymbol{\Delta})$ do not differ in slope $(P>0.05)$. In (b), competition by radioinert $\mathrm{PL}(\xi)$ for hepatic binding of ${ }^{125} \mathrm{I}$-labelled goat PL does not parallel that exhibited by bovine $(O)$ or goat $(O)$ growth hormones.

\section{Radioimmunoassay of goat PL}

Of 3 rabbits immunized, useful antisera were obtained from 2 after several months of boosting with small quantities of goat PL. The antiserum characterized for use had an operational titre $\left(\mathbf{B}_{0}\right.$ less non-specifically bound c.p.m. equal to $50 \%$ of total added ${ }^{125}$ I-labelled PL less non-specifically bound c.p.m.) of 1:44000 (final dilution) but was used at 1:64000 in assays to maximize sensitivity. Sensitivity, defined as the lowest standard distinguishable from zero, was consistently $190 \mathrm{pg}$. Neither crude extracts made from goat pituitaries nor purified goat GH or prolactin at doses up to $1000 \mathrm{ng}$ were detected (Fig. 5), and volumes of $<200 \mu \mathrm{l}$ plasma or serum from male goats and nonpregnant females, and a variety of culture media containing $10 \%$ fetal bovine serum contained no detectable PL.

Plasma concentrations of PL in 6 goats from 40 to 60 days of pregnancy are shown in Fig. 6(a). The hormone was first detected $(>1 \mathrm{ng} / \mathrm{ml}$ ) in jugular plasma on Day 44 (range Days 44-48, mean Day 46) and concentrations increased rapidly, initially doubling every 1.5 days. Concentrations of PL for a selection of later stages of pregnancy are shown in Fig. 6(b); maternal levels were highest in mid- to late-pregnancy and does with triplets had the highest concentrations of PL. High concentrations of PL were measured in amniotic fluid collected on Days 119, 125 and 126 from a doe with twins: amniotic values were 524, 294 and $148 \mathrm{ng} / \mathrm{ml}$ while maternal plasma concentrations were 


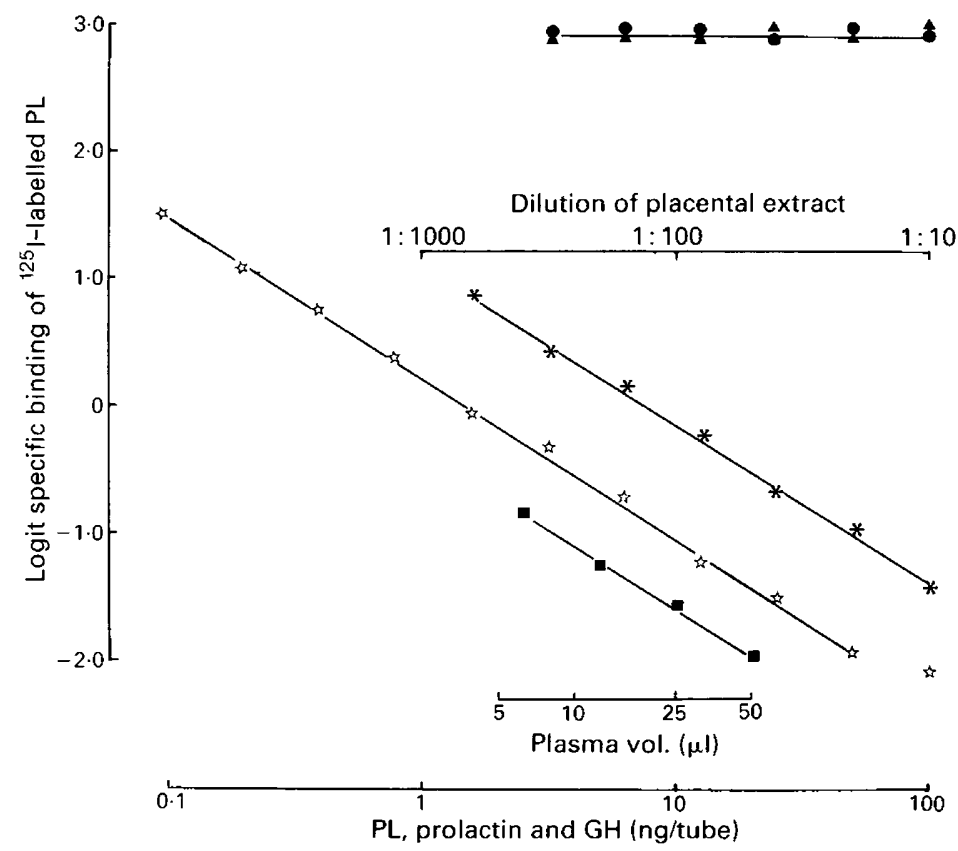

Fig. 5. Selectivity of the radioimmunoassay for goat placental lactogen. Logit-transformations of $\%$ specific binding of ${ }^{125} \mathrm{I}$-labelled goat PL for the bleed and dilution of rabbit anti-goat PL used routinely for radioimmunoassay purposes. Binding competition using up to $100 \mathrm{ng}$ per tube of PL ( $\vec{i})$, goat growth hormone $(\boldsymbol{\theta})$ and goat prolactin $(\boldsymbol{\Delta})$ are shown along with serial dilutions of a goat placental extract equivalent to the starting material used for purification $\left({ }^{*}\right)$ and various volumes of plasma from a ditocous goat in late pregnancy $(\boldsymbol{\square})$. Dilutions of a goat pituitary extract, plasma from a non-pregnant goat and tissue culture media containing $10 \%$ (v/v) fetal bovine serum were without effect and are not shown.

1004,818 and $887 \mathrm{ng} / \mathrm{ml}$, respectively. Changes in plasma concentrations of PL around parturition, measured at $6 \mathrm{~h}$ intervals in 3 goats, are shown in Fig. 6(c); values declined gradually throughout the $36 \mathrm{~h}$ pre partum, decreased rapidly after parturition, and were undetectable by $18 \mathrm{~h}$ post partum.

\section{Discussion}

A simple and rapid procedure for purification of goat PL from fetal cotyledons is described. Consistently low placental content of the hormone in the goat, often $<5 \mu \mathrm{g} / \mathrm{g}$ wet weight $(0.000083: 1$, on an extractable protein basis) has posed considerable difficulties throughout this work. The methodology exploits the basic (pI 8.35) nature of the hormone by the sequential use of exclusion anion exchange followed by a more conventional cationic exchange chromatography, the combination of which affords an approximate 500-600-fold purification within the first day of the procedure. The protocol developed for the CM-cellulose is devised so that the monitoring of $\mathrm{pH}$ and absorbance obviates the need for assaying PL. At the scale of isolation described here, chromatofocussed PL can be finally purified by gel filtration using very small volumes (1-2 ml) of applied sample. During pilot studies, that initially required up to 10 days to complete the purification, considerable loss of PL was a common occurrence and recoveries of PL were substantially improved when individual steps were devised that minimized delays.

The method described here for the purification of GH and prolactin permits rapid processing of small numbers of pituitaries to achieve purification of $20-40 \mathrm{mg}$ quantities of the hormones within 


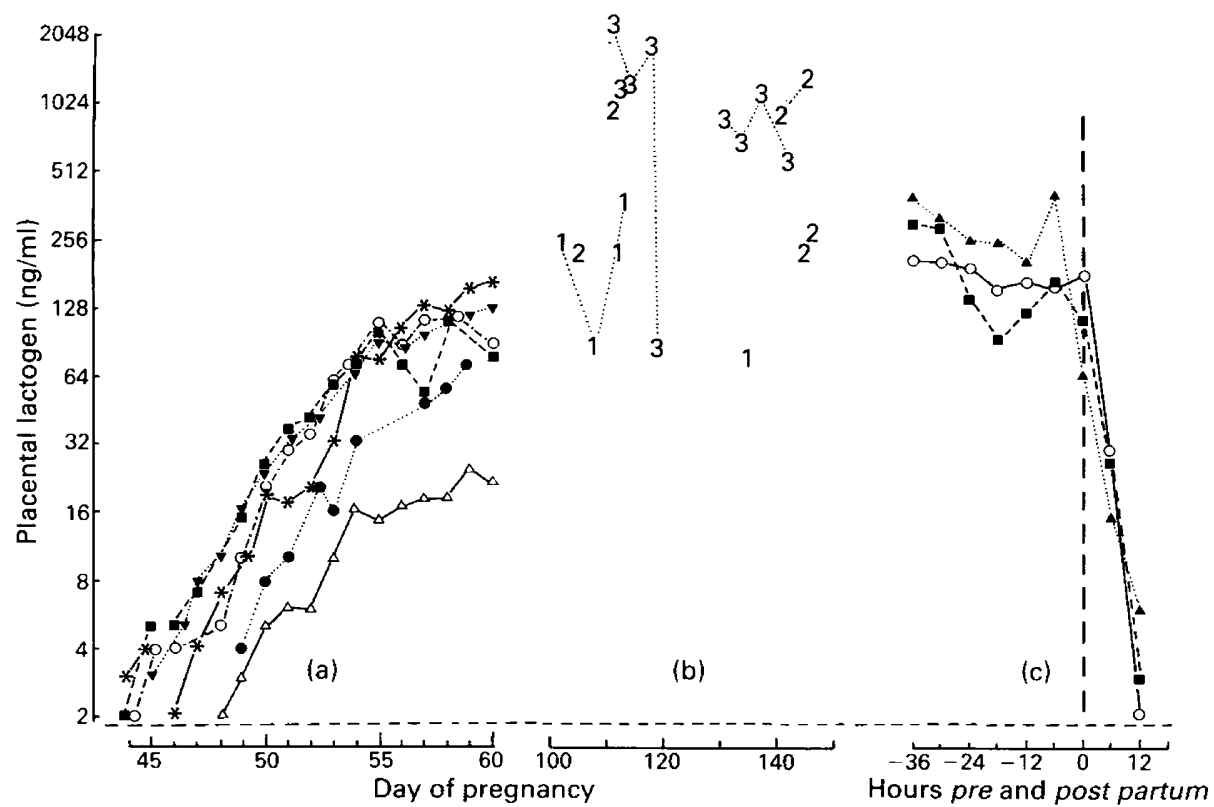

Fig. 6. Placental lactogen concentrations in maternal jugular plasma from pregnant goats. The assay sensitivity was $1.9 \mathrm{ng} / \mathrm{ml}$ (broken horizontal line). (a) First detection of PL in 6 goats was on Day 44 . One goat $\left({ }^{*}\right)$ subsequently delivered triplets while the others carried twins; measured concentrations initially doubled every 1.5 days. (b) Concentrations measured during the last third of pregnancy are shown for goats carrying single (1), twin (2) and triplet (3) fetuses. Samples from the same animals are shown connected. (c) Changes in PL concentrations around parturition (vertical broken line) are shown for 3 animals, one with a single fetus (open symbols) and 2 that delivered twins (closed symbols). The hormone could not be detected in samples collected at $18 \mathrm{~h}$ post partum.

$72 \mathrm{~h}$. Based on the work of McNeilly \& Andrews (1974), the partial coelution of GH and prolactin from Sephadex G-100 operated in a semi-preparative mode is exploited, and by using the same buffer for gel filtration and subsequent chromatofocussing, delays between the steps are minimized. Polybuffer components were eliminated by salt precipitation and gel filtration, as for goat PL.

Electrophoresis of the purified goat hormones, PL, GH and prolactin, indicated molecular sizes of 22500,21500 and 23500 respectively. There was no indication of contamination by components of other size. Analytical isoelectricfocussing indicated pIs of 8.35, 7.3 and 5.6 for PL, GH and prolactin, respectively. Most batches of goat PL contain a trace contaminant of pI 8.0 and the GH preparation examined in Fig. 3 shows the presence of a slightly more basic contaminant.

On the basis of relative binding in the GH-RRA, our preparation of GH has a potency of $93 \%$ that of Miles bGH, Lot 13, or $1.12 \mathrm{IU} / \mathrm{mg}$ using the commercial preparations as a reference. For goat prolactin, the relative binding in the prolactin-RRA was $51 \%$ that of bovine prolactin $(\mathrm{NIH}$, B-18) or $14 \mathrm{IU} / \mathrm{mg}$. These crude estimates of potency from the RRAs merely provide an indication that the electrophoretically homogeneous preparations (Fig. 4) can be expected to exhibit acceptable biological potencies. At this level of scaling, the methods described yield $20-40 \mathrm{mg}$ quantities of the two hormones. Such amounts are useful for electrophoretic and radioimmunoassay reference preparations and as test materials for in-vitro studies in which goat hormones are required.

When compared to pituitary $\mathrm{GH}$ and prolactin in RRAs using rabbit microsomes, goat PL has a dry weight potency of $2.2 \mathrm{GH}$ units $/ \mathrm{mg}$ and 28.5 prolactin units $/ \mathrm{mg}$. This preparation can be compared to the partly purified material obtained by Becka et al. (1977) and a brief description of goat PL by Chan et al. (1986). Becka et al. (1977) fractionated medium conditioned by short-term 
explant culture of goat cotyledons and obtained a product of apparent $M_{\mathrm{r}} 22000$ by gel filtration, and $\mathrm{pI} 8.8$ by preparative focussing. Their peptide was not purified to the extent described here and no potency information was obtained. More recently, Chan et al. (1986) briefly described a preparation of goat PL that seems to be more equivalent to that obtained in our work. They describe two forms (PL-I and II) with $M_{\mathrm{r}}$ values of 22 000-23000 with minor contaminants of 28000 and 35000 . Potencies of their preparations, based on RRAs, were equivalent to those of sheep GH, prolactin and PL.

Useful antisera were obtained from 2 of 3 immunized rabbits after a protracted series of boosts. In routine use, one serum at 1:64000 final dilution bound 30-35\% of 20000 total added c.p.m. of ${ }^{125}$ I-labelled goat PL with non-specific binding ranging between 1 and $3 \%$ of total labelled hormone. Standard competition curves using $190 \mathrm{pg}$ to $50 \mathrm{ng}$ PL per tube provide acceptable linearity after logit-log transformation. A standard dose of $100 \mathrm{ng}$ displaced bound ${ }^{125}$ I-labelled goat PL into the vicinity of tubes lacking antiserum.

Antiserum binding of ${ }^{125} \mathrm{I}$-labelled PL and standard curves constructed as above were insensitive to various added volumes of serum or plasma from non-pregnant goats. Similarly, the related pituitary hormones, goat GH and prolactin, while not purified to the same degree as was PL, were quite satisfactory for testing possible cross-reactivity with anti-goat PL. Dilutions of a crude goat placental extract, but not that of a pituitary extract, exhibited parallelism to purified goat PL standards. Minor cross-reactivity $(5-10 \%)$ with sheep PL, purified to a similar degree by the same methodology (W. B. Currie, unpublished), was observed in most bleeds from the immunized rabbits.

Plasma samples from pregnant goats that contained high, moderate and low endogenous concentrations of PL were enriched with purified PL before assay and quantitative recoveries were obtained (regressions of amount measured against amount added were $>0.9$ ). Additionally, samples with high endogenous concentrations were assayed at various dilutions and measured concentrations, adjusted for dilution, agreed within 5-7\%, values comparable to within-assay variability.

Concentrations of PL were undetectable in jugular plasma samples from goats during the first 5 weeks of pregnancy, corroborating earlier findings with far less sensitive RRAs (Currie et al., 1977; Hayden et al., 1980). The first appearance of goat PL occurred on Day 44 which agrees with an earlier report using the RIA described here (Card et al., 1988). Concentrations increased to peak levels during the last third of pregnancy and does bearing triplets had the highest peripheral concentrations of PL. Maternal levels of goat PL were shown by Hayden et al. (1979) to be correlated with fetal number. The hormone was detected in amniotic fluid. Concentrations of PL declined pre partum, and were undectectable by $18 \mathrm{~h}$ post partum. Further comprehensive studies characterizing endocrine changes in pregnant goats and using the RIA for goat PL have been performed (Card, 1989).

This work was supported in part by the New York State Agricultural Experiment Station.

\section{References}

Becka, S., Bilek, J., Slaba, J., Skarda, J. \& Mikulas, I. (1977) Some properties of goat placental lactogen. Experientia 33, 771-772.

Buttle, H.L., Forsyth, I.A. \& Knaggs, G.S. (1972) Plasma prolactin measured by radioimmunoassay and bioassay in pregnant and lactating goats and the occurrence of a placental lactogen. $J$. Endocr. 53, 483-491.

Card, C.E. (1989) The biology of placental lactogen, growth hormone and prolactin in the pregnant dairy goat and her fetus. Ph.D. thesis, Cornell University.

Card, C.E., Butler, W.R., Currie, W.B. \& Michel, F.J.
(1988) Caprine placental lactogen (PL): feto-maternal levels, short term changes and ketosis. Biol. Reprod. 38 (Suppl. 1), 269, abstr.

Chan, J.S.D., Nie, Z-R., Seidah, N.G. \& Chretien, M. (1986) Purification and characterization of caprine placental lactogen (cPL). Biol. Reprod. 34 (Suppl. 1), 76 abstr.

Currie, W.B. \& Thorburn, G.D. (1977) The fetal role in timing the initiation of parturition in the goat. In The Fetus and Birth (Ciba Fndn Symp. No. 47), pp. 47-66. Eds J. Knight \& M. O'Connor. Elsevier, Amsterdam. 
Currie, W.B., Kelly, P.A., Friesen, H.G. \& Thorburn, G.D. (1977) Caprine placental lactogen: levels of prolactin-like and growth hormone-like activities in the circulation of pregnant goats determined by radioreceptor assays. $J$. Endocr. 73, 21 5-226.

Forsyth, I.A. (1974) The comparative study of placental lactogenic hormones: A review. In Lactogenic Hormones, Fetal Nutrition and Lactation, pp. 49-67. Eds J. B. Josimovitch, M. Reynolds \& E. Cobo. Wiley, New York.

Hayden, T.J., Thomas, C.R. \& Forsyth, I.A. (1979) Effect of number of young born (litter size) on milk yield of goats: Role for placental lactogen. J. Dairy Sci. 62, 53-57.

Hayden, T.J., Thomas, C.R., Smith, C.V. \& Forsyth, I.A. (1980) Placental lactogen in the goat in relation to stage of gestation, number of fetuses, metabolites, progesterone and time of day. J. Endocr. 86, 279-290.

Hayden, T.J., Buttle, H.L., Rees, P.L., Smith, C.V. \& Forsyth, I.A. (1983) Simultaneous determinations of uterine blood flow and plasma concentrations of placental lactogen in late-pregnant goats. $J$. Reprod. Fert. 69, 503-510.

Kelly, P.A., Robertson, H.A. \& Friesen, H.G. (1974) Temporal pattern of placental lactogen and progesterone secretion in sheep. Nature, Lond. 248, 435437.
Kelly, P.A., Tsushima, T., Shiu, R.P.C. \& Friesen, H.G. (1976) Lactogenic and growth hormone-like activities during pregnancy determined by radioreceptor assays. Endocrinology 99, 765-774.

Laemmli, U.K. (1970) Cleavage of structural proteins during assembly of bacteriophage $\mathrm{T}_{4}$. Nature, Lond. 227, 680-685.

McNeilly, A.S. \& Andrews, P. (1974) Purification and characterization of caprine prolactin. $J$. Endocr. 60, 359-367.

Shiu, R.P.C., Kelly, P.A. \& Friesen, H.G. (1973) Radioreceptor assay for prolactin and other lactogenic hormones. Science, NY 80, 968-971.

Talamantes, F., Jr (1975) Comparative study of the occurrence of placental prolactin among animals. Gen. comp. Endocr. 27, 115-121.

Talamantes, F. \& Ogren, L. (1988) The placenta as an endocrine organ: polypeptides. In The Physiology of Reproduction, pp. 2093-2144. Eds E. Knobil \& J. Neill. Raven Press, New York.

Tsushima, T. \& Friesen, H.G. (1973) Radioreceptor assay for growth hormone. J. clin. Endocr. Metab. 37, 334-336.

Received 26 September 1989 